\title{
Virtual Learning Centers for XXIst Century Organizations
}

\author{
G. Paquette \\ LICEF Research Centre, Télé-université \\ 1001 Sherbrooke est, Montréal, Qc, Canada, H2L 4L5 \\ E-Mail: gpaquett@teluq.uquebec.ca \\ Web: http://www.teluq.uquebec.ca/ licef/
}

\begin{abstract}
A model of the Virtual Campus is introduced as a result of course development at Télé-université, as well as a product of the research conducted at its research center, LICEF. The Virtual Campus model is based on the networking of a diversified array of actors and resources. Its aim is to offer an access, in real time and in asynchronous mode, to a variety of learning resources: other learners, trainers and tutors, content experts, managers and designers. These different actors communicate with distant computer-based servers offering multimedia documents, courseware, integrated tools for task achievement and training, individual or group message files, projects and activities. We present here a survey of six different telelearning models describe LICEF's Virtual Campus model, its actors and their functions, the process in which they participate and the role they play, as well as the virtual spaces of resources they use. We also present five different implementations of the model and we outline future research and development in this field.
\end{abstract}

\section{Résumé}

Le concept de campus virtuel est ici exploré et présenté dans le contexte de la Téléuniversité et de son centre de recherche, le LICEF. Le Campus virtuel proposé repose sur la mise en réseau d'acteurs et de moyens diversifiés. Il vise à offrir un accès, en direct et en différé, à diverses ressources d'apprentissage: autres apprenants, formateurs et tuteurs, experts de contenu, gestionnaires, professeursconcepteurs. Ces différents acteurs ont accès à des serveurs informatiques leur offrant des documents multimédias, des logiciels, des outils de travail et de formation, des fichiers de messages individuels ou collectifs, des travaux à réaliser. Nous présentons six modèles techno-pédagogiques de formation à distance, puis nous exposons le modèle de Campus Virtuel du LICEF, ses acteurs et leurs fonctions, les processus auxquels ils participent et les rôles qu'ils y jouent, ainsi que les cinq espaces virtuels dans lesquels ils évoluent. Nous faisons aussi état de cinq implantations du modèle, ainsi que des perspectives de recherche et de développement dans ce domaine.

\section{Keywords}

Virtual campus, Tele-learning, Roles, Actor, Scenario, Virtual space learning 


\section{INTRODUCTION}

Télé-université was created shortly after the United Kingdom's Open University, in 1972. It is Canada's oldest distance teaching university. Most of its students $(90 \%)$ are working adult learners. LICEF is Télé-université's research center. Its mission aims to further knowledge in cognitive informatics, particularly through its applications according to three axes: knowledge modeling of learning transactions, learning systems engineering methods and the development of computerized telelearning systems.

The Virtual Campus concept has become LICEF unifying's research project (Paquette 1995). The design of our Virtual Campus is based on the networking of actors and resources that are much more diversified than in most other existing telelearning systems. It aims to offer learners synchronous or asynchronous access to various learning resources such as trainers and tutors (animation, pedagogical assessment, advice, monitoring) contents experts (information resources), managers (organization, coordination, accreditation), professors-designers (continued updating of learning resources). On the information highways, many resources are available to the different actors through servers: multimedia documents, educational software, working and learning tools, individual or teleconferencing message files, individual or group productions.

In this article, we will review the main techno-pedagogical models in distance education in order to establish the orientation principles of a virtual campus. Then, we will present LICEF's model of the Virtual Campus, its actors and their functions, the process in which they participate and the roles they play, as well as the virtual spaces where they evolve. Finally, we will summarize the implementation of this model as experimented at LICEF and Télé-université and we will conclude on the research and development outlook.

\section{DISTANCE EDUCATION TECHNO-PEDAGOGICAL MODELS}

Distance education covers a multi-facetted techno-pedagogical reality, ranging from the simple decentralization of classroom activities to interactive multimedia models that make learning available whatever the time or the location. We now describe these various models and stress the principles that we have retained to design an integrated model of the Virtual Campus.

\subsection{Distance education technological models}

The distance education world is bubbling. The rapidly evolving availability of multimedia telecommunication is giving way to a increasing number of technopedagogical models. We describe them in terms of six main paradigms: 
- The enriched classroom where technologies are used within a traditional setting in order to do a presentation, a demonstration or an experimentation. It is a networked classroom allowing access to campus resources and external databases and it is sometimes called an "intelligent" campus.

- The virtual classroom (Wilson and Mosher, 1994 ; Hiltz, 1990) mainly uses videoconferencing to support distant learners and teachers, thereby re-creating a telepresence type of classroom ; many university campus now have their own multimedia production studios so they may decentralize training at satellite locations.

- The teaching media (Pea and Gomez, 1992 ; Bourdeau et al., 1994) is focused on the learner's workstation. It allows access to prefabricated multimedia course contents on CD ROM, either shipped by mail or available from a distant multimedia server. Instruction and didactic resources are offered in such a way that the learner can individualize his own learning process.

- Information highway training is also centered on the learner's workstation, which serves as a navigation and research instrument to find all kinds of useful educational information. Essentially, a "Web course" is offered on a central site where instructions and pointers related to didactic resources (other Web sites) are gathered in order to accomplish learning activities.

- The communication network (Henri et Rigault, 1993; Rigault et Henri, 1990) uses the workstation, not only as a media support or as a way to access information, but also as a synchronous (desktop videoconferencing, screen sharing, etc.) and as an asynchronous communication tool (electronic mail, computer teleconferencing, etc.). In this case, technology is used to support learners and resource people within the context of team work or group discussion.

- The performance support system (EPSS) (Gery, 1997) concerns task-oriented training modules that are added to an integrated support systems within a workplace. Information has a "just in-time " quality and training is seen as a process that is complementary and incorporated into the work process.

Each of these models has advantages and drawbacks. The first two are very popular at the present time. They rest on the traditional paradigm inherent in live information transmission: the teacher uses computerized and audiovisual equipment to animate a real-time multimedia group presentation, broadcast locally or to several distant locations where learners are gathered. This model requires costly equipment as well as the learners and teacher's physical presence simultaneously. Moreover, too often it reduces the learners' interaction and initiative to a level that is in no way better than that of a traditional course presentation in an auditorium. 
This approach appears incapable of meeting the growing training needs in a socioeconomic context where lifelong learning, sought by busy and mobile people, involves cognitive abilities of a much higher level than what was required in the past. As pointed out by a recent report produced by Quebec's Higher Council for Education.

- "From now on, the emphasis must bear on higher cognitive abilities (reasoning, problem solving, planning) and social abilities (autonomy, communication and collaboration). These are consistent with the capabilities expected from workers following the impacts of information and communication technology on the very nature of work".

- Rapport annuel 1993-94 du Conseil supérieur de l'éducation, Gouvernement du Québec, p. 24 (free translation by LICEF).

The availability of Internet and multimedia technologies exposes the learner to numerous sources of information among which he must make choices. The new paradigm (figure 1) where the learner, at the center of his learning process calls on many expertise sources, is better represented by the last four models described above than by the first two.

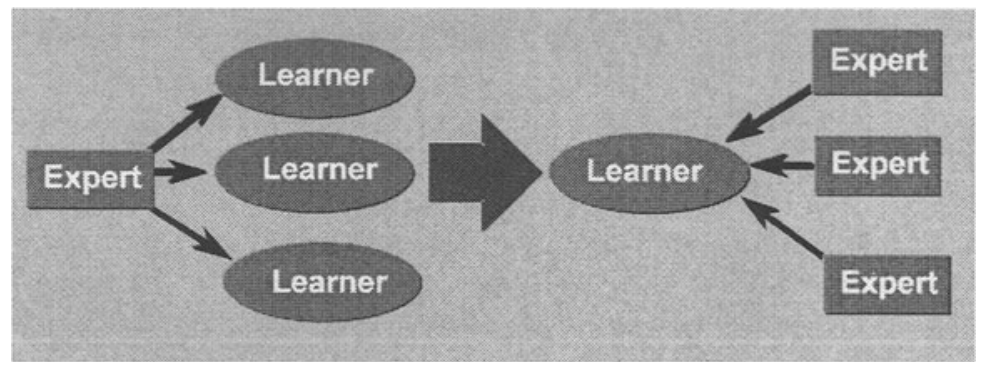

Figure 1. Paradigm shift

In the models of the " teaching media " or the " information highway training" and their application as it is currently, training is personalized but it is also deprived of an important collaborative dimension. However, this dimension can be reinstated if we use the computer as a tool to communicate. As for the EPSS approach, it favors two principles: just-in-time information and learning seen as information processing. The learning scenario concept at the heart of our Virtual Campus proposal is based on these principles. 


\subsection{Principles that rule the learning systems}

The study of these different models and their integration into a constructivist point of view suggest ten principles that should guide the engineering and use of learning systems in the context of the Virtual Campus:

1. A learning system is centered on the learner. The other actors (trainers, managers, informants and designers) activities are defined according to the learners activities.

2. A learning system fully uses the distance as an asset to facilitate lifelong learning. It must be available whenever and wherever the learner may pursue his learning process.

3. A learning system proposes a constructivist pedagogy by bringing forward the learner's pro-activity in building his own knowledge, by taking into account his characteristics and by helping him integrate available information, within a context and usage, that is to say by helping him transform information into knowledge.

4. A learning system is process-oriented in the sense that the learner builds his knowledge by solving problems, by accomplishing tasks and realizing projects.

5. A learning system offers just-in-time learning by making information available at the moment it is required.

6. A learning system must induce the development of knowledge and skills that will enable learners to search, find and process information adequately; it must facilitate the development of transfer abilities as well as a high level of autonomy in the learning process.

7. A learning system aims to develop social skills and positive attitudes in regard to learning.

8. A learning system offers the different actors various ways of accessing and processing information, such as software environments available for research and communication, for process-related advice, for collaboration among learners as well as among learners and other actors who facilitate the learning process.

9. A learning system supports the learning process through various integrated means within a coherent set of objectives, tools and methods. 
10. A learning system is open, that is to say it can be adapted by learners or trainers to the particular needs of learners, teams or groups of learners from different surroundings or cultures. It is modular in order to facilitate its adaptation, updating or its re-engineering.

\section{THE VIRTUAL CAMPUS MODEL}

Based on the ten principles just stated, we now introduce the model of the Virtual Campus designed by LICEF: Its actors and their roles, the process and the technological tools needed by its actors in order to assume their functions in an integrated telelearning system.

\subsection{Actors and process}

The learning process is ruled by an actor called "learner" who transforms information into knowledge. "Information" here signifies any data, concrete or abstract, perceptible by the senses and susceptible of being transformed into knowledge. "Knowledge" means that information has been absorbed and integrated by a cognitive entity into its own cognitive system, in a situated context and use.

Transforming information into knowledge by the learner requires the adaptation of pre-existing mental structures or the creation of new ones, which are always integrated to the entire mental system of the learner. Knowledge so created is integrated into a usage as long as it is used in a process that allows the learner to act in his environment.

Information, the starting point of the learning process, is made available to the learner by another actor called " informer". The informer may be a person or a group of persons that intervene directly, sometimes calles content experts. But it may also be a book, a video, a software or any other material or media that makes part of a knowledge domain available as usable learning information.

"Collective Knowledge" is any socially recognized knowledge. It can be from a general field such as physics or management or a specialized know-how related to the use of a software program or a specific work method in an organization.

We introduced the two indispensable actors in any learning process:

- The LEARNER rules his learning process and transforms information into knowledge.

- The INFORMANT rules the information process, communicates and makes available part of a body of knowledge. 


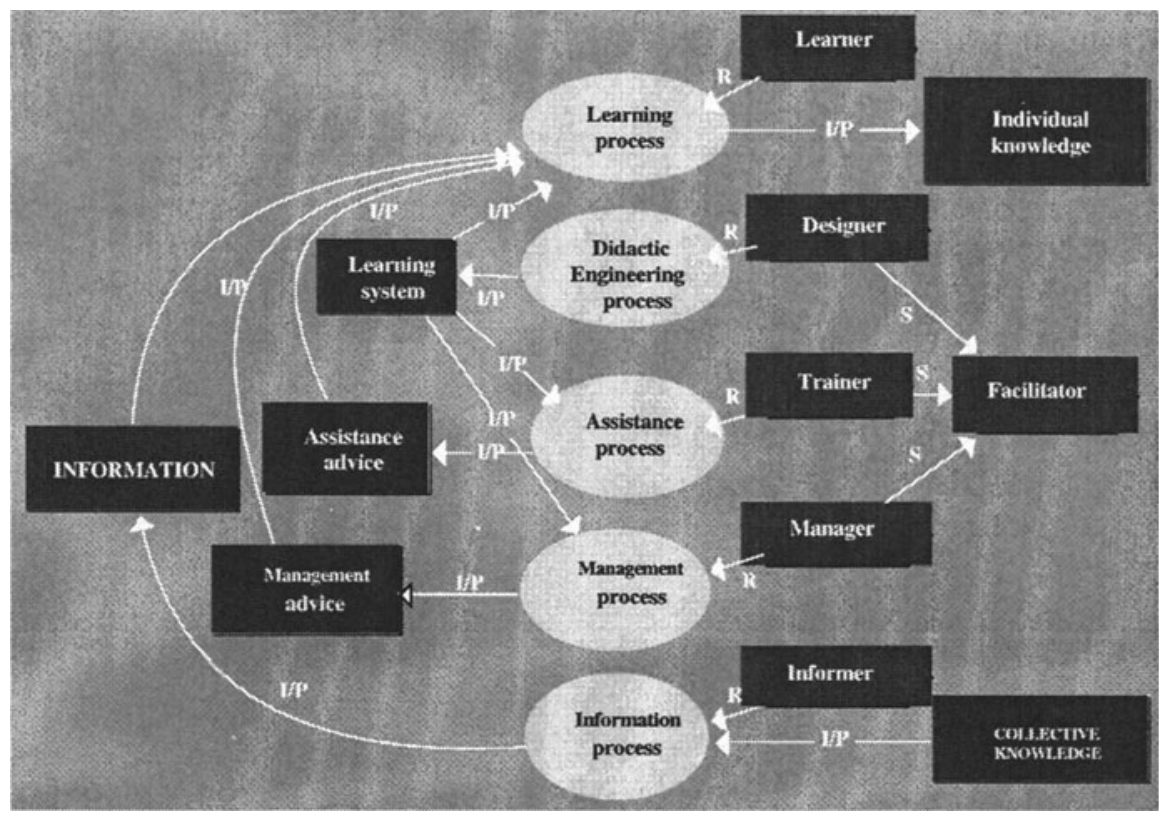

Figure 2. Actors and main telelearning process

- The DESIGNER, rules the didactic engineering process, facilitates learning by building, adapting and maintaining in working order, a learning system (LS) that integrates information sources (human informants or didactic instruments), communication, interaction and collaboration tools intended for the actors, as well as assistance and advice mechanisms (human trainers or computerized help).

- The TRAINER rules the assistance and pedagogical advice process, facilitates learning by giving advice to the learner about his individual process and the interaction that may be useful to him based on the learning scenarios defined by the " designer" actor.

- The MANAGER rules the pedagogical management, facilitates learning by managing actors and events in order to insure the success of the process, based on the scenarios defined by the " designer" actor.

Depending on the specifics of a learning systems, the different actors roles may be filled by a smaller or larger number of people and sub-systems. In traditional class training, for example, the informer and facilitator roles are most often carried out by the same teacher. On the other hand, in the case of autonomous learning through correspondence courses, the learner receives all the learning materials in a kit containing didactic multimedia or multiple media instruments. In performance 
training, for example, the informer and facilitator roles are most often carried out by the same teacher. On the other hand, in the case of autonomous learning through correspondence courses, the learner receives all the learning materials in a kit containing didactic multimedia or multiple media instruments. In performance support systems, information is available through a computerized environment that is also the learner's work environment.

\subsection{Functions and actors roles}

Figure 2 shows an overall view of the functions the different actors can take on. We define a function as the process pertaining to an actor and by which he intervenes in a learning situation. There are as many functions as there are actors, each one being associated with its input and product, as well as with the actor that assumes the function.

At this point, each one of the five major functions assumed by one of the actors of the Virtual Campus is described by a "black box". We know its input and product but not its contents. To determine the contents, we must describe the process through the chain of more or less complex tasks and actions that make up this process, each task's input and product and the principles that rule their execution.

We call " role" any generic process used as a component to define one or the other actors' function in the context of the learning process. A role, then, is a sub. process of the main process which represents the generic function of an actor in a telelearning system.

Table 1 describes, for each actor and his related function, some of the roles or sub-processes that contribute to the function.

We would like to point out that a given role may appear in the function description of more than one actor. For example, the role of explorer of external databases, even though included in the definition of the learner's function, might also be part of another actor's functions.

It must be said that actors are different from typical task functions as defined by a given organization and they must also be distinguished from individuals (participants) that assume the function and the roles. For example, at Téléuniversité, professor is a task function often covering the roles of the actor "designer" (minus the production of non-printed documents), of the actor " informer" (while training tutors or directly dealing with learners) and the actor "manager" (while supervising tutors). The tutor is another task function who assumes some, but not all, of the roles of the actor "trainer" and the actor " manager" at the same time.

Finally, individuals can be the ultimate incarnation of the actors as well as the task functions. For example, professor $X$ is a participant who acts as the actor " designer" of this course while professor $\mathrm{Z}$ is another participant who assumes the function of informer. 


\begin{tabular}{|c|c|}
\hline ACTOR AND FUNCTION & ROLES OR CORRESPONDING SUB-PROCESS \\
\hline $\begin{array}{l}\text { LEARNER } \\
\text { (Transforms information into } \\
\text { knowledge) }\end{array}$ & $\begin{array}{ll} & \text { Navigator in the learning scenario } \\
\text { - } & \text { Explorer of Internal documentation sources } \\
\text { - } & \text { Explorer of external databases } \\
- & \text { Problem solver } \\
\text { - } & \text { Producting of asty in a project } \\
-\quad \text { Self-appraiser of his activities } \\
\text { - } & \text { Social actor } \\
\text { - } & \text { Comater in a telediscussion } \\
\end{array}$ \\
\hline $\begin{array}{l}\text { TRAINER } \\
\text { (Facilitates learning) }\end{array}$ & $\begin{array}{ll} & \text { Diagnostic producer } \\
- & \text { Advisor } \\
\text { - } & \text { Appraiser of learners assignments } \\
-\quad \text { Teams an using the environment } \\
\text { - }\end{array}$ \\
\hline $\begin{array}{l}\text { DESIGNER } \\
\text { (Builds, adapts and maintains a } \\
\text { learning system) }\end{array}$ & $\begin{array}{ll} & \text { Training needs analyst } \\
- & \text { Knowledge model maker } \\
- & \text { Pedagogical scenario builder } \\
- & \text { Priter of learning systems plans and cost estimates } \\
-\quad \text { Producer of didactic instruments } \\
-\quad \text { Designer of the system's production plan } \\
\text { - Producer and director }\end{array}$ \\
\hline $\begin{array}{l}\text { MANAGER } \\
\text { (Manages actors and events) }\end{array}$ & $\begin{array}{ll}- & \text { Planner } \\
- & \text { Decision maker } \\
- & \text { Controller } \\
- & \text { Director of broadcasting operations } \\
- & \text { Teams and groups organizer } \\
- & \text { Learnimentation and validation organizer } \\
- & \text { Learning system assessment director } \\
- & \text { Network manager }\end{array}$ \\
\hline $\begin{array}{l}\text { INFORMER } \\
\text { (Makes information available) }\end{array}$ & $\begin{array}{ll} & \text { Information presenter } \\
- & \text { Content clarification expert } \\
- & \text { Manager of mediated knowledge } \\
-\quad \text { Trace analyzer } \\
\text { - }\end{array}$ \\
\hline
\end{tabular}

Table 1. - Actors in the Virtual Campus and some of their roles 


\subsection{Specific roles and scenarios}

A library of roles that can be played by one or many actors is a central element in our model of the Virtual Campus. These roles are described in a structured way so as to define precisely each actor's function in a given learning system. Considered as a process, each role can be defined by a graph of tasks that comprises procedures (or tasks) to be executed by the actor, the links between them, their input and product as well as the principles that govern them.

We call such a graph a "generic scenario". Hence, a generic graph of the tasks describes each possible actor's role. By combining generic scenarios, by adapting them and making them more specific to a knowledge domain, we can describe precisely each actor's function in a given learning system (Paquette, Aubin and Crevier, 1997 ).

Let us take, for example, the role of "problem solver". Since there are several types of problems, such as classification, diagnostic or design, we can specialize this scenario according to the nature of the problem. Then, a generic diagnostic scenario might become a central element in a more global learning scenario, being followed by a remedial scenario for example. Moreover, since the trainer needs to diagnose the learners progress, a diagnostic scenario can be integrated into the training scenario as well, serving as a basis for the trainer's intervention in the learning process.

A specific actor's scenario results from personalizing the generic scenarios that have been retained as applicable to his function in this particular learning system.

Hence, let us suppose that we intend to build a telelearning system about automobile mechanics. The learner's specific scenario would include tasks such as searching for information in technical guides, followed by a diagnostic process applied to some system in an automobile, then, by a telediscussion session about this type of diagnostic and finally by an self-assessment about automobile mechanics diagnostic. Four generic scenarios will have been combined and specifically adapted according to the field of study in order to generate a specific learning scenario.

Moreover, in the same telelearning system, the trainer will have to play the role of "advisor" according to the learners search about automobile diagnostic, to do so, he will also use the generic diagnostic scenario but will apply it in the hope of identifying the learner's difficulties in solving this type of problem. He will then animate the telediscussion and insure (generic scenario of supervision) that each learner correctly completes his self-assessment. We then obtain, for the same situation, a specific training scenario. 


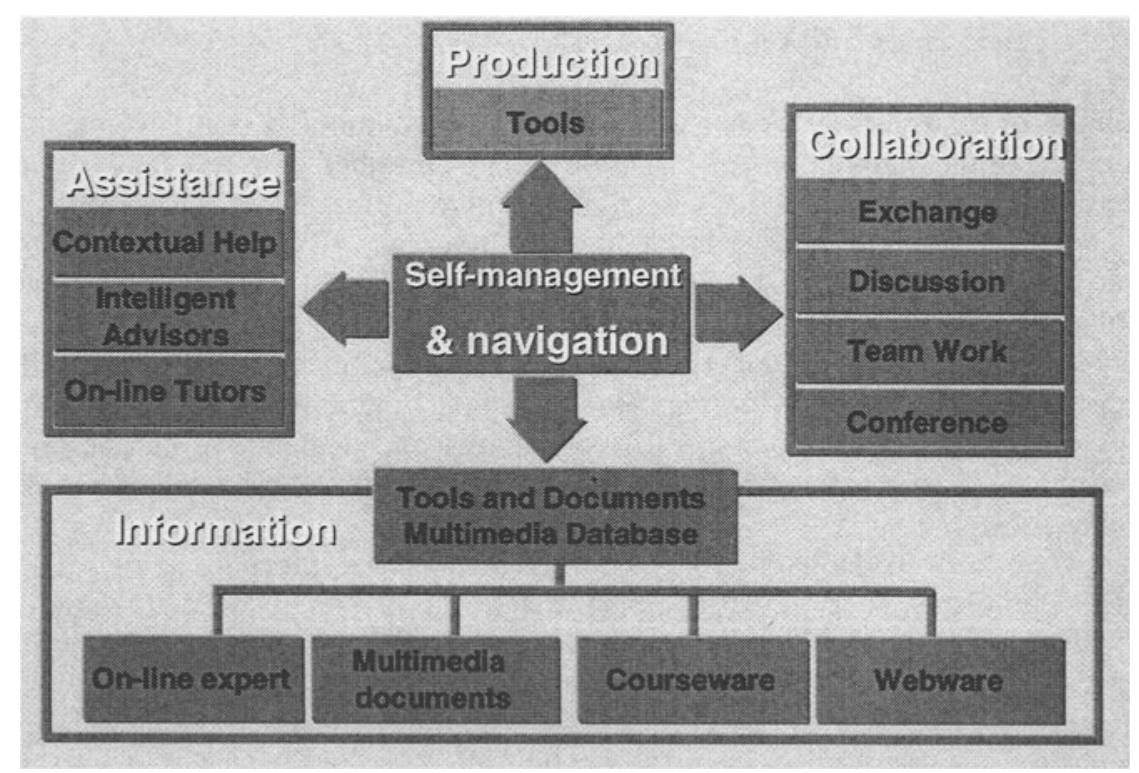

Figure 3. A telelearning system's five virtual spaces

\subsection{The actors virtual spaces}

In an object-oriented perspective (Rumbaugh et al, 1991), examining the process governed by the different actors allows us to infer technological objects that can be useful to effectively play their roles in a telelearning system. Whatever the actor, we may hence discover five virtual spaces, as described on figure 3 , in which each actor evolves in his own fashion.

This telelearning software environment is called an "HyperGuide". It is composed of five spaces: self-management and navigation, information, production, collaboration and assistance.

On the actor for whom it is intended, each one of these HyperGuide environments provides an access to various services. Among them, the Scenario navigator allows the actor to navigate in his scenario and gives him a way to access other available tools such as self management tools: notes assignments, diary, workplan, or knowledge model navigator.

Each actor also benefits from:

- An information space in which are gathered various types of documents and data needed to fulfill his function, including multimedia documents, web sites and on-line content experts; 
- A production space in which are gathered the tools needed to produce assignments or to intervene in the learning system, for example text editors, spreadsheets or simulators;

- A collaboration space in which are gathered the tools needed to exchange files with other participants, to realize team work, to participate in telediscussion or seminar through various forms of synchronous or asynchronous teleconferencing.

- An assistance space where help, advice or an adaptation of his environment are available from a resource person or the computerized system.

The production space is represented by a work and production workbench allowing a given actor to accomplish the tasks that have been defined in his scenario. In the case of the actor DESIGNER, it will be, for example, the telelearning systems engineering workbench (AISTA) ${ }^{11}$ that enables him to navigate in the scenarios of the telelearning systems engineering method (MISA), so that he can define the plan and specifications of the learning system and specify the other actors HyperGuide environments.

\section{IMPLEMENTATIONS OF THE VIRTUAL CAMPUS}

One of the advantages of the Virtual Campus model presented here is its adaptability to different technological contexts and the modularity that makes its components reusable. The speed of technological evolution makes it necessary to design such open models so that learning systems can evolve without the need to rebuild from scratch every time a new type of pedagogical material becomes available. This model's versatility is illustrated through five courses developed at Télé-université or prototypes developed at LICEF, implemented during the last six years.

Table 2 summarizes each project according to characteristics such as: the knowledge domain; the pedagogical model, at the heart of which are the learning scenarios defining each actor's role (here only the learner is considered); and finally, the media model including the pedagogical material, the tools and the technological infrastructure needed to deliver the telelearning system.

The first implementation shows that the model is independent of technology. It is a multiple media course that does not use telematic tutoring or on-line collaboration tools. The navigation-management space uses such media as printed guides that describe activities and productions to be realized by the learner as well as text, video and software information sources. The communication and collaboration space is composed of meetings and telephone conversations. The assistance space consists of telephone tutoring and examples of software usage included in a printed technical guide.

1. AISTA in an extension actually being developed at LICEF of AGD, a course design performance support system (Paquette et al, 1994). 


\begin{tabular}{|c|c|c|c|c|c|}
\hline $\begin{array}{c}\text { Components } \\
\text { of the LS }\end{array}$ & $\begin{array}{c}\text { Traditional } \\
\text { multiple media }\end{array}$ & HyperGuide 1 (1992) & $\begin{array}{c}\text { Internet course } \\
(1994)\end{array}$ & COVI (1996) & CECO (1997) \\
\hline $\begin{array}{l}\text { Knowledge } \\
\text { model (types of } \\
\text { knowledge } \\
\text { units) } \\
\end{array}$ & $\begin{array}{l}\text { Introduction to } \\
\text { artificial } \\
\text { intelligence } \\
\text { (concepts) }\end{array}$ & $\begin{array}{l}\text { Introduction to } \\
\text { instructional design } \\
\text { (procedures) }\end{array}$ & $\begin{array}{l}\text { Introduction to } \\
\text { Internet } \\
\text { (procedures) }\end{array}$ & $\begin{array}{l}\text { Training and } \\
\text { competiti- } \\
\text { veness } \\
\text { (concepts) }\end{array}$ & $\begin{array}{l}\text { Training and } \\
\text { competiti- } \\
\text { veness } \\
\text { (concepts }\end{array}$ \\
\hline $\begin{array}{l}\text { Learning } \\
\text { scenario }\end{array}$ & $\begin{array}{l}\text { Readings in a } \\
\text { book, video, } \\
\text { problem solving } \\
\text { with specialized } \\
\text { software }\end{array}$ & $\begin{array}{l}\text { Case study and course } \\
\text { design activities }\end{array}$ & $\begin{array}{l}\text { Search on Internet } \\
\text { to achieve a project }\end{array}$ & $\begin{array}{l}\text { Virtual } \\
\text { colloquium : } \\
\text { research, } \\
\text { commu- } \\
\text { nication, } \\
\text { synthesis and } \\
\text { presentation }\end{array}$ & $\begin{array}{l}\text { Virtual } \\
\text { colloquium : } \\
\text { research, } \\
\text { commu- } \\
\text { nication, } \\
\text { synthesis and } \\
\text { presentation }\end{array}$ \\
\hline $\begin{array}{l}\text { Navigation- } \\
\text { management } \\
\text { space }\end{array}$ & $\begin{array}{l}\text { Printed guide and } \\
\text { cross-reference } \\
\text { to texts, videos } \\
\text { and software }\end{array}$ & $\begin{array}{l}\text { HyperCard to } \\
\text { describe interactive } \\
\text { scenarios and manage } \\
\text { the learning activities }\end{array}$ & $\begin{array}{l}\text { Netscape pages } \\
\text { describing the } \\
\text { interactive } \\
\text { scenarios, giving } \\
\text { access to } \\
\text { collaboration and } \\
\text { assistance tools }\end{array}$ & $\begin{array}{l}\text { Scenario } \\
\text { navigator; } \\
\text { Metaphorical } \\
\text { representation } \\
\text { of the virtual } \\
\text { colloquium }\end{array}$ & $\begin{array}{l}\text { Scenario } \\
\text { navigator; } \\
\text { Personal } \\
\text { management } \\
\text { tools; } \\
\text { Generic shell } \\
\text { of the Virtual } \\
\text { Campus }\end{array}$ \\
\hline $\begin{array}{l}\text { Information } \\
\text { space }\end{array}$ & $\begin{array}{l}\text { Monography } \\
\text { grouping the } \\
\text { texts, eight } 30 \\
\text { minutes videos } \\
\text { and } 6 \text { software } \\
\text { programs }\end{array}$ & $\begin{array}{l}\text { On-line file containing } \\
\text { chapters, } \\
\text { a printed version of } \\
\text { the manual and an off- } \\
\text { line video cassette }\end{array}$ & $\begin{array}{l}\text { Netscape pages } \\
\text { locally or on } \\
\text { Internet giving } \\
\text { access to } \\
\text { documents and } \\
\text { tools }\end{array}$ & $\begin{array}{l}\text { Text } \\
\text { documents } \\
\text { integrated in } \\
\text { the } \\
\text { environment; } \\
\text { videos on CD } \\
\text { ROM or server }\end{array}$ & $\begin{array}{l}\text { Text and video } \\
\text { documents } \\
\text { integrated in } \\
\text { the } \\
\text { environment } \\
\text { or on a server }\end{array}$ \\
\hline $\begin{array}{l}\text { Production } \\
\text { space }\end{array}$ & $\begin{array}{l}\text { Printed } \\
\text { templates; } \\
\text { Generic software } \\
\text { tools: text editor, } \\
\text { spreadsheet,.....; } \\
\text { computer } \\
\text { printouts } \\
\text { using specialized } \\
\text { software }\end{array}$ & $\begin{array}{l}\text { Hypercard } \\
\text { templates linked to } \\
\text { acitivity pages } \\
\text { Generic software } \\
\text { tools: text editor, } \\
\text { spreadsheet,..... }\end{array}$ & $\begin{array}{l}\text { Generic software } \\
\text { too's: text editor, } \\
\text { spreadsheet,..... }\end{array}$ & $\begin{array}{l}\text { Generic } \\
\text { software tools: } \\
\text { text editor, } \\
\text { spreadsheet,... } \\
. .\end{array}$ & $\begin{array}{l}\text { Generic } \\
\text { software tools: } \\
\text { text editor, } \\
\text { spreadsheet,... } \\
. . ; \\
\text { FX-Notes } \\
\text { application }\end{array}$ \\
\hline $\begin{array}{l}\text { Communicatio } \\
\text { n and } \\
\text { collaboration } \\
\text { space }\end{array}$ & $\begin{array}{l}\text { Telephone } \\
\text { tutoring; } \\
\text { Two meetings } \\
\text { with tutor }\end{array}$ & $\begin{array}{l}\text { E-mail; } \\
\text { File transfer; } \\
\text { Computer textual tele- } \\
\text { conferencing }\end{array}$ & $\begin{array}{l}\text { E-mail } \\
\text { File transfer } \\
\text { Computer textual } \\
\text { teleconferen-cing }\end{array}$ & $\begin{array}{l}\text { Asynchronous } \\
\text { tools (e-mail, } \\
\text { files, computer } \\
\text { conferencing) } \\
\text { Synchronous } \\
\text { (bi-point } \\
\text { videocon- } \\
\text { ferencing and } \\
\text { white board on } \\
\text { RNIS) }\end{array}$ & $\begin{array}{l}\text { Asynchronous } \\
\text { and } \\
\text { synchronous } \\
\text { tools } \\
\text { multipoint } \\
\text { videocon- } \\
\text { ferencing, } \\
\text { white board on } \\
\text { cable modem, } \\
\text { ADSL and } \\
\text { ATM } \\
\text { networks }\end{array}$ \\
\hline $\begin{array}{l}\text { Assistance } \\
\text { space }\end{array}$ & $\begin{array}{l}\text { Telephone } \\
\text { tutoring } \\
\text { Guide and } \\
\text { examples of } \\
\text { software use }\end{array}$ & $\begin{array}{l}\text { Telematic tutoring } \\
\text { Hypercards for advice } \\
\text { \& examples linked to } \\
\text { each activity }\end{array}$ & $\begin{array}{l}\text { Telematic tutoring } \\
\& \text { teleconfe-rencing }\end{array}$ & $\begin{array}{l}\text { Tutoring in } \\
\text { synchronous } \\
\text { and } \\
\text { asynchronous } \\
\text { modes }\end{array}$ & $\begin{array}{l}\text { Tutoring in } \\
\text { synchronous } \\
\text { and asynchro- } \\
\text { nous modes } \\
\text { Learner's trace }\end{array}$ \\
\hline
\end{tabular}

Table 2. - Five implementations of the Virtual Campus model 
The second implementation of the Virtual Campus model uses simple technological means. This HyperGuide is hypermedia software produced with HyperCard or Toolbook that describes the scenario of available activities through clickable buttons. These lead to an activity summary page that includes instructions, objectives and icons leading to documents to be consulted in order to achieve the activity or serving as assignment templates. The information space is composed of documents (printed and videos) that may be consulted or produced by the learner. Each document is represented by an icon giving access to a text or to the summary of a video. The collaboration space is represented by other icons giving access to electronic mail and computer teleconferences integrated into each module's scenario. The assistance space uses advice or example cards offering help linked to a specific activity. These files are displayed at the learner's demand. The learner can also choose to communicate with his tutor or his team members by using e-mail (Paquette, Bergeron and Bourdeau, 1993 ).

The third implementation, an introductory course to the Internet, has similar characteristics. However, it uses support on the Internet or locally, with the Netscape browser. Web pages describe the learning activities to be achieved, hyperlinks giving access to documents to be consulted and tools to be used to complete assignments and projects. Asynchronous tools such as e-mail and teleconferencing facilitate collaborative work as well as tele-tutoring.

The last two examples are more advanced prototypes developed at the LICI:F Research Centre (Paquette et al, 1995 ). In both cases, a course in economics was constructed. The intended goal was to facilitate collaborative learning by using contents that had modular qualities. The metaphor was that of a virtual colloquium or conference center. In both cases, students had the necessary means to accomplish research and team production of reports that were then presented to the group within the virtual conference. Various mechanisms were implemented at the workstations to allow access to multimedia production and communication documents and on-line advice by tutors. However, in the second case, the environment was much richer compared to the first example since the course was run within the larger context of a computerized Campus model. Many media, including server-based video were use. Self-management, group management and production tools were also included. Finally, a full network support was provided for desktop video conferencing and white board facilities, as well as asynchronous teleconferencing using cable-modem, ADSL and ATM broadband technology. This last experiment has proven the feasibility of an heterogenous networking of a group a students using different network support, while still being able to undertake various collaborative learning activities. 


\section{CONCLUSION}

The Virtual Campus model just presented offers an advantage in that it facilitates the implementation of functional capabilities that are required by the system's different users. It also makes it possible to verify that all spaces and tools needed by the participants are adequate and designed following a systemic perspective according to each of the five actors points of view in a given learning system. The model also enables us to take into account the various levels in a complex telelearning system and, consequently, to see better each required tool's anchoring point. This is because the model makes a clear distinction between the generic Virtual Campus level and the more specific level of an actual learning system or a course.

Moreover, to facilitate as much as possible the model's generic characteristic as well as its independence from the various means of implementation, the architecture platform that supports the system was designed using a layered approach. In this fashion, the physical networks level is as isolated as possible from the applications level. Between the two, the middle layer supports the computer program intended to enable the implementation and execution of different scenarios by linking them with physical means and software. It is at this particular level that LICEF's actual research and development efforts are focused. It should lead to the production of a new prototype in 1998, enabling designers to build Virtual Campus environments more easily.

At the same time, the model is also the starting point for the huge plan undertaken by Télé-université to re-engineer its technological infrastructure and its 250 courses, taking into account the means available to students at home and in the workplace today, together with their probable evolution. Télé-université expects to put all of its courses in a Virtual Campus environment in the coming four years, using various degrees of technology integration.

The Virtual Campus model presented here was also adapted to help define UQAM's campus-distance model (SAMM project), as a virtual partnership campus with three other universities or superior schools (ETS, INRS and UQAM), as well as to the development of the turnkey computerized school model, supported by Quebec's Education Ministry.

\section{ACKNOWLEDGMENTS}

The author wishes to underline the contribution of Claude Ricciardi-Rigault, Chantal Paquin, Ileana de la Teja and all the teams who participate in the various Virtual Campus projects at LICEF and have helped these ideas to develop. Also, a special thank to the Quebec Information Highway Fund and the TeleLearning National Network of Centers of Excellence, who have contributed to the funding of these projects. 


\section{REFERENCES}

Bourdeau J., Frihida A., Gecsei J., Paquette G., De la Teja I. (1994). Accessing distributed multimedia documents for instructional use. ED-Media International Conference, Vancouver, September 1994.

Gery G. (1997). Granting Three wishes through Performance-Centered Design NATO Communications of the ACM, volume 40 , number 7, pp.54-59, July 1997.

Henri F., Ricciardi Rigault C. (1994). Collaborative Learning and Computer Conferencing. NATO Advanced Workshop, Grenoble, Sept.1993; to be published in T.T. Liao (Ed) Advanced Educational Technology: Research Issues and Future Potential, Springer-Verlag, Berlin.

Hiltz S. (1990). Evaluating the Virtual Classroom, in Harasim, L. (ed.) Online education: perspectives on a new environment. New-York: Praeger, 133-184.

Paquette G., Aubin C. and Crevier, F. (1997). Design and Implementation of Interactive TeleLearning Scenarios. Proceedings of ICDE'97 (International Council for Distance Education), PennState University, USA, June 1997.

Paquette G., Crevier, F. and Aubin C. (1997). Méthode d'ingénierie d'un système d'apprentissage (MISA). Revue Informations In Cognito, numéro 8, 1997.

Paquette G., Ricciardi-Rigault C., Paquin C., Liégeois S. and Bleicher E.(1996). Developing the Virtual Campus Environment, ED-Media International Conference, Boston, USA, June 1996.

Paquette G., Ricciardi-Rigault C., Bourdeau J., Paquin C., Liégeois S.(1995). Modeling a Virtual Campus Environment for Interactive Distance Learning, ED-Media International Conference, Graatz, Austria, June 1995.

Paquette G., Modeling the Virtual Campus (1995). In "Innovating Adult Learning with Innovative Technologies (B. Collis and G. Davies Eds) Elsevier Science B.V., Amsterdam, 1995.

Paquette, G., F.Crevier, C. Aubin (1994). Knowledge in a Course Design Workbench. Educationnal Technology, USA, volume 34, n. 9, pp. 50-57, November 1994

Paquette G., Bergeron G., Bourdeau (1993). The Virtual Classroom revisited, Conference TeleTeaching'93, Trondheim, Norway, August1993.

Pea R., \& Gomez L. (1992). Distributed multimedia environments. Interactive Learning Environments, 2, 73-109.

Ricciardi-Rigault, C., Henri, F. (1994). Developing Tools for Optimizing the Collaborative Learning Process, Proceedings of the International Distance Education Conference, June, Pennstate.

Rumbaugh J., Blaha M., Premerlani W., Eddy F. \& Lorensen W. (1991). ObjectOriented Modeling and Design. Engl. Cliffs, NJ : Prentice Hall.

Spector M., Polson M. \& Muraida D. (1993). Automating Instructional Design: Concepts and Issues. Engl. Cliffs, NJ: Educational Technology Publications.

Wilson J. \& Mosher D. (1994). The Prototype of the Virtual Classroom Journal of Instructional Delivery Systems, Summer 1994, 28-33. 


\section{BIOGRAPHY}

Gilbert Paquette is director of the LICEF Research Centre of Télé-université, he is involved in instructional design support systems, knowledge modeling techniques and tools, advisor system design and HYPERGUIDES, the main Virtual Campus project in Quebec. He is active in three international research consortia, has published three books and directed a dozen-distance learning multimedia course or courseware development. 